\title{
Sustainability And Integrated Reporting In The South African Corporate Sector ${ }^{1}$
}

Anria S. van Zyl, Stellenbosch University, South Africa

\begin{abstract}
This article aims to determine if the adoption of Integrated Reporting by large private sector companies in South Africa has led to an improvement in the quality of sustainability-related information disclosed. This was done in two stages. The first stage comprised a literature review with the aim to develop an evaluation matrix that can be used to access the quality of the sustainability-related information being disclosed within Integrated Reports. During the second stage, empirical evidence was obtained by assessing the sustainability reporting disclosures made by the best performers according to the Johannesburg Stock Exchange (JSE) Sustainability Index. The Integrated Reporting process is still in the development phase with many companies only now developing methodologies to measure their various impacts. The study found that, although many companies are attempting or claiming to be creating Integrated Reports, the level of integration is still very low. Few companies have incorporated or understood the importance of environmental and social sustainability in achieving long-term success. It is hoped that this research will provide an evaluation matrix to assess the information disclosed within Integrated Reports as well as provide insights into the implementation challenges experienced by the early adopters in South Africa.
\end{abstract}

Keywords: Sustainability; Integrated Reporting; Evaluation Matrix; Environmental Sustainability; Social Sustainability; Economic Sustainability

\section{INTRODUCTION}

\section{Background}

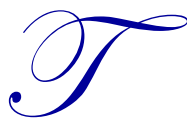

he first decade of the 21 st century saw a growing realisation that humanity is facing a "poly-crisis." The current global economic crisis, which started with the collapse of the financial system in 2008/2009 (Tapscott, 2010, p. ix), is intertwined with increased socio-economic inequality, fears surrounding food and water security (Roberts, Keeble \& Brown, 2002, p. 2), dwindling resources, and a planet that is reaching its ecological limits (IRC 2011, p. 3). Climate change, ecosystem degradation, and the loss of biodiversity (Haberl, Fisher-Kowalski, Krausmann, et al., 2011, p. 5) are not merely side-effects of the global industrial system. They form an intrinsic part of how the entire system is "constituted, fuelled and financed" (Swilling \& Annecke, 2012, p. 48).

The globally synchronised economic slump is "not an accidental event" (Perez, 2010, p. 1), but is the result of the culmination of two cyclical patterns. The first marks the end of the current development cycle which began in the early 1950's. These development cycles recur, on average, every 60 years. The current global recession can be interpreted as "a blocked structural transition at a global scale." Viewed together with the current environmental crisis and resource constraints, it is clear that business as usual is no longer an option (Gore, 2010, p. 716).

The current economic crisis extends beyond a purely financial crisis and "failure to address it soon will have more than cyclical consequences" (Eccles \& Krzus, 2010, p. 1). If existing consumption patterns and production methods are not addressed, it is likely that we will reach a point where livelihoods are no longer

${ }^{1}$ This is a reprint from the International Business \& Economics Research Journal August 2013, Volume 12, Number 8. 
sustainable (Zukang, 2011, p. v), which will eventually lead to complete and irreparable system collapse (Diamond, 2011). A new "green" development paradigm needs to be developed to build more equitable, low-carbon, resourceproductive and zero-waste economies (Swilling \& Annecke, 2012, p. 69).

The second cyclical pattern has to do with the manner in which technological revolutions are assimilated within the market system. Perez identified five major technological revolutions in the last 240 years, each containing a major technological bubble midway along the assimilation of each technological revolution (Perez, 2009 , p. 780,2010 , p. 1-2). These bubbles mark the turning point between the "installation" and "deployment" phases of each revolution (Swilling \& Annecke, 2012, p. 66) and are triggered by the financial opportunities created by new technologies and results from the dysfunctional relationship between production capital and financial capital (Gore, 2010, p. 720).

The negative economic impact of the cyclical pattern associated with the current Information Revolution was amplified by the effects of the "double bubble," the dot.com bubble of 1997-2000, and the Easily Liquidity Bubble (ELB) of 2004-2009. According to Perez, these two bubbles are "two stages of the same phenomenon" (Perez, 2009, p. 780). In a normal cycle, the dot.com crash would have triggered the "deployment" phase where more realistic production capital takes over from speculative financial capital (Perez, 2010, p. 2). Various interventions by the Federal Reserve and neoliberal governments lead to a Ponzi-type ELB, characterized by massive concentrations of investments in paper assets and increased decoupling from the real economy. The paper economy eventually lost its value in 2007-2008 (Perez, 2009, p. 780; Swilling \& Annecke, 2012, p. 61).

The interaction between production capital and financial capital is essential for the market economy. Production capital is a wealth creator and, with its long-term bias, is more suitable to create sustainable growth. Financial capital is flexible and mobile with a short-term bias, it reallocates wealth, and is essential to "force" new paradigm changes (Perez, 2010, p. 2-3).

The ELB experienced in 2007-2008 resulted from a fundamental change in the structure of the market economy (Perez, 2009, p. 801). State interventions allowed the financial world to remain in control of investment. Instead of investing in technological opportunities in the real economy, the abundant cheap credit searched for speculation opportunities. The new opportunities created by the Information Revolution saw the emergence of "futures, commodities, private capital buyouts, hedge funds, derivatives" and an array of "synthetic instruments from securitised mortgages to mutual hedging and credit default swaps" (Perez, 2009, p. 791-2).

In order to remain competitive and ensure the loyalty of investors, production companies started to avoid long term projects and focussed on short-term gains measured in quarterly profits (Perez, 2009, p. 789). Under increasing pressure from investors with a bias toward financial profits, many non-financial corporations started to increase their investment portfolios "to an extent that an increasing portion of their profits came from capital gains or dividends" (Perez, 2009, p. 799). When the bubble finally burst, many companies were forced into bankruptcy and it again highlighted the growing concern among stakeholders that current financial reporting practices enables business leaders to conceal unsustainable business strategies (Roberts, Keeble \& Brown, 2002, p. 2).

Recovery from the current recession is more serious and complex than that of a "purely" financial crash. Policy and institutional changes should not merely be focussed on increasing overall investment and growth (Gore, 2010, p. 725), but it should be guided towards investments that will ensure the transition into a sustainable development cycle.

South Africa, with its carbon intensive economy, is currently the 12th largest $\mathrm{CO} 2$ emitter in the world (National Treasury, 2010, p. 3). Significant changes to government policies and strategies, corporate behaviour and public consumption patterns will be required in order to decouple economic growth from greenhouse gas emissions. These policy and institutional changes are made more challenging due to difficulties in reconciling environmental and sustainability issues with the conflicting relationships between poverty eradication, unemployment, low levels of education and service delivery, while still ensuring economic growth (DEAT, 2010, p. 4; Robb, Tyler \& Cloete, 2010). 
The only way to ensure sustainable development is through environmental policies that ensure that the actions of individuals, businesses and government are sustainable (Connelly \& Smith, 2003, p. 161-162), yet many economists and businesses still criticize government policies that influence or dictate the behaviour of individuals and organisations (Clarke, Willis \& Brown, 2000, p. 285). The corporate sector still maintains that self-regulation and voluntary codes of conduct will be more effective and efficient that any "government-imposed regulations or command-and-control regimes" (Elliot, 2004, p. 119).

There is, however, a "widely-held suspicion" that individuals and businesses will not voluntarily take the required actions needed (Connelly \& Smith, 2003, p. 172) to achieve sustainable and equitable development. Corporate activity is a major direct and indirect cause of environmental decline through pollution, resource and environmental service exploitation, investment strategies, and environmental and social impacts of international trade (Elliott, 2004, p. 116).

In the context of the current global recession and increasing evidence that the current economic model is environmentally and socially unsustainable, and growing concerns that the current corporate reporting practices are insufficient, new forms of accountability and increased transparency are being sought (King, 2011, p. 1). The King code of Governance Principles for South Africa 2009 (referred to as King III) states that "current incremental changes toward sustainability are not sufficient - we need a fundamental shift in the way companies and directors act and organise themselves" (IoD, 2009, p. 9). King III recommends the adoption of Integrated Reporting and the Integrated Report as an important element of this "fundamental shift" (King, 2011, p. 1).

\section{The Emergence of Integrated Reporting}

The preparation and filing of financial reports emerged out of the Great Depression of the 1930's in an attempt to provide potential investors with sufficient information to make informed investment decisions (King, 2011, p. 1). These reports have gradually grown increasingly complex and voluminous due to ever-increasing accounting standards and disclosure requirements, yet they are increasingly less relevant and useful for analysts and investors as they are difficult for "even the most sophisticated users to understand" (Eccles \& Krzus, 2010, p. 51-52, 56). Corporate reporting based only on accounting standards are also increasingly being criticised as it allows companies to externalise environmental and social costs due to the fact that financial results are not placed within the context of the greater economy, society or the environment in which the firms operate (Terry, 2008, p. 178).

During the 1990s, some companies started to voluntarily produce non-financial reports reflecting stakeholder calls for more informed corporate disclosure (King, 2011, p. 1). The content of these reports varies considerably, but in general, it contains information regarding environmental, social and/or economic performance in a printed format (Visser, Matten, Pohl et al., 2010, p. 293). Corporate social responsibility, sustainability, and triple bottom-line reporting has emerged as a thriving industry, with almost all major corporations now issuing annual reports detailing their social and/or environmental performance (Christian Aid, 2004, p. 1,2; Norman \& MacDonald, 2004, p. 244; Munshi \& Kurian, 2005, p. 513). The premise behind these non-financial reports is that only the impacts that are measured and accounted for in a report will receive the necessary attention by the organisation's management and owners. Reporting is therefore seen as essential to ensure that organisations are socially and environmentally responsible (The Economist, 2009).

These "sustainability" reports have had little impact on the mainstream financial accounting and corporate reporting methodologies. In fact, it would seem that there are currently more "non-financial" reporting, but it has had little success in making business more accountable and responsible as evidenced by the fact that "at macro level, almost every indicator of our social, environmental, and ethical health is in decline" (Visser, 2011a, p. 7-8). Major weaknesses of sustainability reports include: 1) that it is often disconnected from the organisation's financial reports, 2) that it is generally backward-looking, and 3) that it fails to provide a link between sustainability issues and the organisation's core strategy (King, 2011, p. 1). These reports have failed to address the distrust among civil society regarding the intentions and practices of business (King, 2011, p. 1) and are still viewed by many as merely a "branch of PR [public relations]" and a tool for improving company reputations (Christian Aid, 2004, p. 1-2).

The recent crisis has also increased awareness that the term "non-financial information" is, in fact, a misnomer. The triple bottom-line that traditionally features in sustainability reporting is often viewed as external to 
the company. There is now a greater understanding that the triple bottom-line will "eventually have an effect on the long-term financial performance of the company" (IoD, 2012, p. 3).

Increased awareness of the need to be accountable to a wider stakeholder community (Visser, Matten et al., 2010 , p. 293) and that the triple bottom-line should rather reflect the triple context (IoD, 2012, p. 3) prompted some companies to independently develop a new form of corporate reporting. The first U.S. company to create an Integrated Report was United Technologies Corporation in 2008. It was followed by American Electric Power and Southwest Airlines in 2009. In Europe, Integrated Reports were developed by the French insurance company AXA, the German chemical company BASF, the Swiss pharmaceutical company Novartis and the Dutch, Van Gansewinkel Group. The Global Reporting Initiative (GRI) reported that approximately 160 companies were producing Integrated Reports in 2010 (Eccles \& Armbrester, 2011, p. 13-14).

In South Africa, the 450 companies listed on the JSE are required to comply with King III and, as a result, have to issue an Integrated Report for financial years starting on/or after 1 March, 2010, or to provide an explanation why they have not done so (IRC, 2011, p. 3). Explaining this step, Mervyn King noted:

It is my belief that integrated reporting represents a significant and much needed evolution of reporting practice and will start influencing behaviour. It is my hope that it will prompt a greater understanding of the sustainability challenges facing humankind. (2011, p. 2)

The integrated reporting process can be visualised as an adapted Deming Cycle, shown in Figure 1. In a perfect integrated reporting process, as envisioned in King III and the Accounting for Sustainability Project, the process would start with a realisation by companies' regarding material sustainability issues and risks faced by them. Companies would then develop action plans and adapt the business strategy to address these risks. Key performance indicators would be developed and the implementation and progress would be monitored. The Integrated Report would then eventually be prepared and it would reflect the challenges and opportunities faced by companies during their journey toward becoming more sustainable, accountable and responsible.

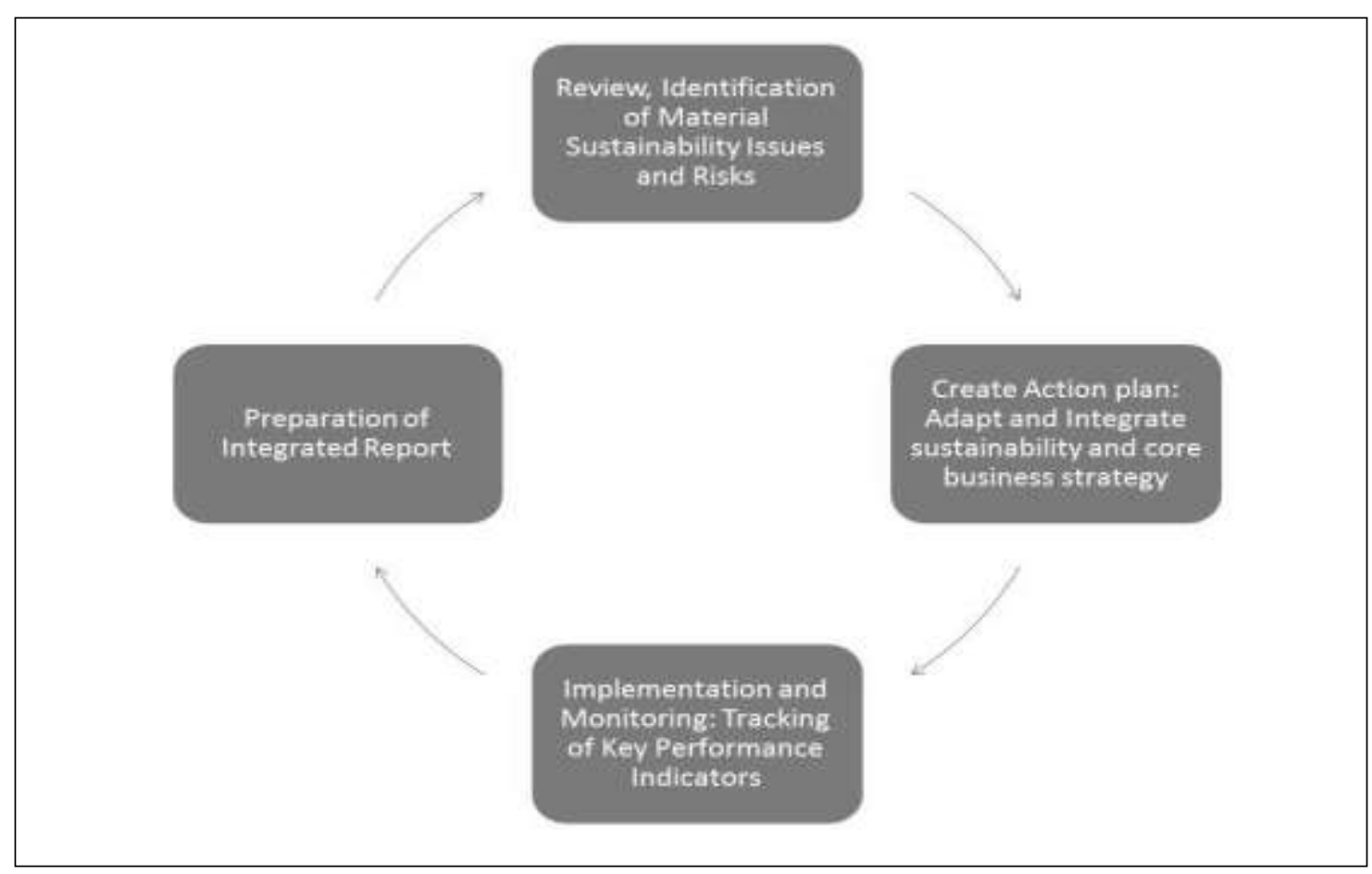

Figure 1: Integrated Reporting Process

(Adapted from A4S, 2007, p. 2) 
This evolution of the reporting process did not, however, happen naturally. By requiring companies to create an Integrated Report, many companies failed to start the process with the development of a clear understanding of the sustainability issues or risks they are meant to be reporting on. Instead, they started the process with the preparation of an Integrate Report and the collection of data points they deem to be important for disclosure purposes. However it is still hoped that the preparation of the Integrated Report would help companies to identify weaknesses and data requirements which would make companies more aware of sustainability issues. This awareness, it is hoped, would lead to changed corporate behaviour and the adoption of a more sustainable business strategy (Eccles \& Krzus, 2010, p. 2-3, 23; IRC, 2011, p. 4).

\section{PROBLEM STATEMENT AND OBJECTIVES}

If the preparation of an Integrated Report leads to more sustainable business processes and a greater awareness of business operations that are unsustainable, the report should contain sufficient information that would enable companies to learn from the process. The report would also reveal that companies are beginning to understand their positive and negative impacts relating to the natural environment and society regarding equity, health, and poverty. This would be evidenced by clear linkages between the identified risks, corporate strategy, and the performance indicators that are measured and disclosed.

This paper aims to empirically test the assumption that the preparation of Integrated Reports will lead to an improvement in the quality of sustainability-related information disclosed and that this disclosure will be sufficient to allow for a meaningful review and learning process by companies. This learning process is essential for companies who wish to become more sustainable.

This review will be performed after the development of an evaluation matrix that can be used to access the quality of the sustainability-related information being disclosed within Integrated Reports. The study has three specific limitations:

- It is limited to the best performers and the findings might not be representative of the sustainability reporting practices of the larger corporate sector in South Africa.

- $\quad$ The content analysis techniques of sustainability reports might have specific limitations, such as the risk of capturing an incomplete picture of the company's business, but "it is a widely accepted and recognised research instrument" (Marx \& van Dyk, 2011, p. 105).

- $\quad$ The study was performed prior to the finalisation of both the Integrated Reporting Committee (IRC) and the International Integrated Reporting Committee's (IIRC) Frameworks on Integrated Reporting and only the provisional guidelines contained in the discussion documents (IRC, 2011; IIRC, 2011) could therefore be considered.

\section{DEVELOPMENT OF AN EVALUATION MATRIX}

\section{Defining Integrated Reporting and the Integrated Report}

Currently, in the absence of the completed framework, there is still no "exact definition of what it means to be doing Integrated Reporting" (Eccles \& Armbrester, 2011, p. 14) and what an Integrated Report should represent. The descriptions and definitions offered by the three main guidance documents available to South African companies; namely, the discussion papers prepared by the IRC, the IIRC, and King III, should be seen in light of the objectives of each of these papers as they address different facets on integrated reporting (IoD, 2012, p. 2).

King III places a strong emphasis on integrated thinking and strategy - in other words, the process of which the outcome is the Integrated Report. King III does not prescribe the format of the Integrated Report; according to the code, the form, is "less important than the substance" and it should provide evidence of the "integrated thinking of the collective mind of the board." King, III therefore operates on a conceptual level. The IRC and IIRC discussion papers focus on implementation proposals (IoD, 2012, p. 4). Without providing a single concise definition, the three documents do provide the following main characteristics which should be associated with an Integrated Report: 
- The report should address material information regarding the company's strategy, performance, prospects, and governance. This information should reflect the commercial, social, and environmental context in which the company operates.

- It should provide evidence which demonstrates that the company is a responsible corporate citizen by reporting on material positive and negative impacts of its activities on the economy, society, and the environment. It should also disclose the companies' dependencies thereon and the related risks.

- It should provide information about how it creates and sustains value as well as the company's prospects for future value creation. In this context, value is no longer understood as being only financial in nature.

(IoD, 2009, 2012, p. 3; IRC, 2011; IIRC, 2011)

\section{Relevant Frameworks, Regulations, Codes and Standards}

The IRC Framework includes guidance on which sustainability reporting and performance frameworks should be considered during the preparation of an Integrated Report (IRC, 2011, p. 5). The list of standards and regulations that were identified (IRC, 2011, p. 5, Deloitte, 2012, p. 94-97, Marx \& van Dyk, 2011, p. 109-110, Terry 2008, p. 154-170, 201-211) and consulted during the literature review, and which informed the framework used during the analysis of the sustainability disclosures of the sampled corporate reports, includes:

- $\quad$ Framework for Integrated Reporting and the Integrated Report. Discussion Paper (IRC, 2011)

- $\quad$ Toward Integrated Reporting: Communicating Value in the $21^{\text {st }}$ Century. Discussion Paper (IIRC, 2011)

- $\quad$ King Code on Governance Principles (King, III) (IoD, 2009)

- $\quad$ Code for Responsible Investing by Institutional Investors in South Africa (IoD, 2011)

- $\quad$ JSE Socially Responsible Investment (SRI) Index Minimum Requirements and Criteria (JSE, 2011b)

- The Global Reporting Initiative Third Generation (GRI G3) Sustainability Reporting Guidelines (GRI, 2011)

\section{Sustainability}

The term "sustainability" is running the risk of becoming over-used and meaningless. Through repetition, "sustainability" is becoming synonymous with attitudes and activities (Gray, 2010, p. 49) which bear little resemblance to what a true sustainable system would look like (Fisher-Kowalski, 2011, p. 153). Scientific research is increasingly showing that most business reporting on sustainability and much of the business activities designed to promote sustainability "actually have little, if anything, to do with sustainability" (Gray, 2010, p. 48). As Professor Rob Gray pointed out:

Indeed these accounts might most easily be interpreted as how organisations would like to understand sustainability and how, in turn, it would convenience them if the body politic would accede to such a view. (2010, p. 48)

Business is in the process of constructing the dominant discourse around sustainability, but in a way which ignores scientific consensus, the development literature, and the development community (Gray, 2010, p. 48; Milne, Ball \& Gray, 2005, p. 1, 12). Barkemeyer et al. found that "there has been a significant shift in the tone of discourse within ... business codes and guidelines, away from the original framing by Brundtland" (2011). These subtle changes in the definition of sustainable development allow companies to choose and use only the codes and guidelines that they consider relevant to their particular view of sustainability. This also allows companies to commit to "sustainability" principles without making tangible commitments toward sustainability. The varying nature of disclosure and the fact that most reports are not independently assured make it difficult to compare the performance of different companies (Norman \& MacDonald; 2004, p. 112, 256).

By benchmarking and awarding the "sustainability" claims of companies made in their corporate reports we are legitimising and reinforcing the very activities that caused our sustainability concerns in the first place (Gray, 2010, p. 58). Benchmarking is, however, essential for investors who need to identify the most socially responsible companies to invest in. 
Many corporations claim to be contributing to the well-being and upliftment of society and the economy by increasing their profits and by providing employment. "Sustainability" in this context, is synonymous with a companies' ability to remain a going concern into the foreseeable future (Milne et al., 2005; Terry 2008, p. 144).

In an attempt to re-align and diminish ambiguity, King III provided a definition of "sustainability" in a business context:

Sustainability of a company means conducting operations in a manner that meets existing needs without compromising the ability of the future generations to meet their needs. It means having regard for the impact that the business operations have on the economic life of the community in which it operates. Sustainability includes environmental, social, and governance issues. (IoD, 2009, p. 61)

The definition is still too vague to allow us to be able to identify whether companies are actively contributing to sustainability or not. The King III definition requires consideration for inter- and intra-generational equity. The traditional triple bottom-line approach is also expanded to include a fourth criteria; namely, governance. This follows the emerging trend for responsible Investor indexes to replace the traditional "economic" criteria in the triple bottom-line with governance (JSE, 2011b, p. 4).

Our ability to define "sustainability" is more than just a linguistic or philosophical exercise; it lies at the heart of the challenge of changing our existing business paradigm. As Gray and Bebbington noted:

The real tragedy is that if sustainable business organizations are ever to be achieved, then societies, individually and collectively, need to know the extent to which corporations, with the very best will in the world, are not capable of delivering sustainability. It is this - accountability for the extent to which a corporation cannot be sustainable, socially responsible and/or environmental benign - that is the real potential of corporate reporting. (Gray, Bebbington, 2007, p. 387)

It is unlikely that we will ever be able to determine a commonly held definition for "sustainability" and "sustainable development"; however, Environmental Governance has developed into a popular strategy to address "unsustainable" development patterns (Kotzé, 2009, p. 103).

\section{Defining “Authentic" Sustainable Development for Corporate Governance}

Sustainability indicators and minimum standards are essential to address corporations' tendencies to make unfounded, unsupported and potentially dangerous sustainability claims (Gray, 2010, p. 57). Recently the U.N. Secretary General, Ban Ki-Moon, indicated that the development of a new sustainable development index, or a set of indicators, would be an important point on the agenda of the Rio+20 Conference (U.N., 2012a, p. 2). This was not achieved at the conference, but paragraph 47 did emphasise the importance of integrating sustainability information into corporate reporting and expressed the need to develop benchmarks and frameworks (U.N., 2012b, p. 8).

King III recommends the use of the Global Reporting Initiative (GRI) reporting guidelines (IoD, 2009, p. 110). Although the GRI seeks to "approximate a notion of sustainability," no attempt is made to derive substantive relationships between the exigencies of global sustainability and organisational activities and the bases of the claims to be an account or a report of sustainability are therefore primarily rhetorical" (Gray, 2010, p. 50).

It should, however, be noted that there are significant gaps between what the various reporting guidelines require and what companies actually end up reporting (Barkemeyer et al., 2011; Gray \& Bebbington, 2007, p. 376; Milne et al., 2005, p. 8). Many of these guidelines, including the GRI, inadvertently allow companies to adopt a "tick-the-box" approach (Terry, 2008, p. 243) allowing companies to adopt a quality management model that only focuses on incremental improvements. The risk of this approach is that the incremental improvements can distract "attention from the larger problems and deeper impacts of the business" (Visser, 2011a, p. 9-10). King III attempts to bridge this problem through promoting the concept of integration and contextualisation; this brings "corporate sustainability" closer in line with the concept of "sustainable development," as enshrined in South African environmental legislation. 
From a legal perspective, all South African companies have to comply with the concept of "ecologically sustainable development" set out in the National Environmental Management Act (NEMA) (South Africa, 1998) and section 24(b)(iii) of the Bill of Rights included in the Constitution (South Africa, 1996). The notion attempts to integrate environmental protection, economic development, and social upliftment into decision-making (Glazewski, 2005, p. 13-14).

As with the King III definition, the NEMA definition poses implementation challenges regarding the weight to be assigned to the different elements (environment, society, and the economy) during decision-making. It also fails to provide definitive guidance regarding the weight that existing stakeholder needs should carry compared to that of future undefined generations.

NEMA Chapter 1 contains 18 national environmental management principles which reflect international trends in sustainable development, such as the precautionary, preventative, and the polluter pays principles. Some of the principles are, however, "peculiar to South Africa and reflect the need to redress the country's apartheid past" (Glazewski, 2005, p. 141-142). These 18 principles, together with the eight sustainable development factors (NEMA Section (2)(4)(a)) (Glazewski, 2005, p. 141), should form the minimum requirements against which sustainable development are measured. With the exception of the last seven principles (Section (2)(4)(l) - (r)), which apply directly to organs of state and government policies, the principles, as applicable, will underpin the evaluation matrix.

\section{Disclosure of the Scope of Sustainability Concerns}

The usefulness and value of the produced report are determined by the scope and boundary decided on by the individual company. This is intrinsically linked to two key concepts: firstly, the manner in which the company chooses to define "sustainability" and secondly, but equally important, is the manner in which the individual firm views "accountability."

"Accountability" can be defined as "the duty to provide an account or reckoning of those actions for which one is held responsible" (Cooper \& Owen, 2007, p. 651). Central to this concept are two questions:

- $\quad$ To whom are companies accountable?

- $\quad$ For what are they responsible?

(Gray, 2006, 2010, 2012; Cooper \& Owen, 2007)

As mentioned earlier, there is currently no single definition of what an Integrated Report should represent, which has led to the development of various interpretations. Broadly speaking, there are currently two schools of thought. The first defines the Integrated Report as:

... an annual report that comprises a holistic and integrated representation of the entity's efforts to enhance and preserve long-term sustainably in all its dimensions without unduly sacrificing short-term performance. (Deloitte, 2012, p. 9, emphasis added)

If a company sees themselves as mainly accountable toward investors (Gray, 2012; Massie, 2010, p. 3-4) and that their sole responsibility is not to "sacrifice short-term performance," it is debatable that the stakeholder engagement process advocated by Integrated Reporting will allow stakeholders to "meaningfully influence specific aspects of corporate decision-making" and that the "decisions reached [will] ... be in the interest of stakeholders other than shareholders" (Cooper \& Owen, 2007, p. 656). From this viewpoint, society and the environment in which the organisation operates is seen as a source of risks and threats to stakeholder wealth and value creation which should be mitigated (Massie, 2010, p. 4). Organisations that are able to convert these risks into opportunities for "value" creation will be successful in the long term. This viewpoint requires companies to clearly disclose to their investors the motivation behind and the associated expenses that will be incurred by their Corporate Social Responsibility (CSR) or Corporate Social Investment (CSI) activities.

The opposing viewpoint sees shareholder value creation as a risk and threat to the long-term sustainability of society and the planet. A company is accountable to stakeholders (of which shareholders are only one group) and 
is responsible to minimise or avoid the negative impacts imposed as a result of their activities on society and the planet (Eccles \& Krazus, 2010, p. 3-4, 23; Massie, 2010, p. 5). Integration is therefore more than just the implementation of new systems and strategies or the writing of cheques, but a deep rooted cultural change within the organisation and by their investors, based on a new set of ethics and moral standards (Visser, 2011b). It is this latter viewpoint in which the Integrated Report reflects "an honest confrontation with the organisation's own unsustainability" (Spence \& Gray, 2007, p. 72) which is more likely to contribute toward "authentic" sustainable development, as it allows companies to look for opportunities to create shared value for themselves and society (Porter \& Kramer, 2006, p. 84). These benefits are then no longer incidental to the company's business (Porter \& Kramer, 2006, p. 88) and companies are less likely to defer these activities in times of economic hardship.

The viewpoint adopted by companies will directly influence their stakeholder engagement process and the subjective judgements used to rank stakeholder concerns (IoD, 2009, p. 100-106). It will also influence their choice regarding the method used to determine materiality. This, in turn, influences which concerns are deemed material enough to form part of the corporate strategy and to be disclosed and discussed within the Integrated Report. The IRC framework concedes that it "necessitates a high degree of judgment, care, and skill" (2011, p. 9). Each company is left to themselves to determine and define their own processes.

"Sustainability" claims made by companies in their reports should be underpinned by evidence of the integration of "authentic" sustainability into decision-making and these decisions are based on an inclusive stakeholder engagement process. The following four aspects should be disclosed:

\section{Integration}

The concept of integration is based on the principles contained in NEMA sections 2(3), 4(b) and 4(i) and can be summarised as follows: social, economic, and environmental impacts are linked and interrelated and all decisions must be based on thorough and integrated assessments, as well as the consideration and evaluation of both the advantages and disadvantages associated with the impacts of activities (South Africa, 1998, p. 11-12). The needs of future generations must also be considered during these assessments (Glazweksi, 2005, p. 16-17).

\section{Stakeholder Engagement}

NEMA sections 4(f) and 4(h) require that all interested and affected parties must be allowed to participate in environmental governance. Equitable and effective participation must be ensured by developing stakeholder understanding, skills, and capacity, as necessary, through "environmental education, the raising of environmental awareness, the sharing of knowledge and experience and other appropriate means" (South Africa, 1998, p. 11-12). King III refers to this as ensuring the "inclusivity of stakeholders" (IoD, 2009, p. 13).

\section{Materiality}

King III stipulates that legitimate interest and expectations of stakeholders must be taken into account (IoD, 2009, p. 13). The concept of materiality attempts to ensure that materiality is set at an appropriate level which still ensures that the interests, needs, and values of all interested and affected parties are taken into account (NEMA section 4(g)). This should be read together with the precautionary principle contained in section 2(4)(a)(vii) which dictates that decisions must take into account the limits of our current understanding and knowledge of potential impacts and that a "risk adverse and cautious approach" must be applied (South Africa, 1998, p. 11-12).

\section{Transparency}

From a legal standpoint, companies are required to comply with the regulations contained in The Promotion of Access to Information Act 2 of 2000 (South Africa, 2000). This act underscores section 32 of the Bill of Rights which stipulates that everyone has the right to access information held by another person or entity that is required "for the exercise or protection of any rights" (South Africa, 1996). NEMA section 4(k) takes this further by stipulating that all development decisions "must be taken in an open and transparent manner" (South Africa, 1998). 
Transparency can be defined as "easy to understand or recognise, balanced, complete, obvious, candid, open, frank, relevant and accessible to stakeholders" (IoD, 2011, p. 9). King III recommends that a company describes how it made its money and that the board ensures that the report is a balanced representation of both positive and negative impacts caused by their operations (IoD, 2009, p. 49).

\section{Disclosure for Environmental Sustainability}

Sustainability should not be seen as a synonym for environmental conservation or preservation. The Environmental Right contained in the Bill of Rights states that ecologically sustainable development should be secured while promoting justifiable economic and social development (South Africa, 1996). NEMA section 2(2) emphasises that environmental management should be people-centred (Glazewski, 2005, p. 141) by stating that: "environmental management must place people and their needs at the forefront of its concern and serve their physical, physiological, developmental, cultural, and social interest equitably" (South Africa, 1998).

Environmental problems are inseparable from other social injustices (Glazewski, 2005, p. 15-16) and, as Wangari Maathai points out, "what happens to the ecosystem affects everything else" (2009, p. 240). The equitable utilisation of natural resources requires consideration for future and present production needs, which requires the implementation of measures aimed at sustaining and preserving biodiversity and environmental functions, which, in turn, is essential for the sustainability of community livelihoods and businesses. It is therefore difficult to distinguish between what is done by society "for the sake of conservation" from what is done purely "for the sake of the economy" (Borrini-Feyerabend, Pimbert, Farvar, et al., 2004, p. 64, 70). The emerging concept of environmental justice will be elaborated further under the section addressing social impacts.

There is a growing trend amongst businesses and business commentators to assume that environmental sustainability equals eco-efficiency. This is also often used to motivate the business case for sustainability and corporate social responsibility (Spence \& Gray, 2007, p. 65). It is undeniable that a company's short-term profitability may be increased through initiatives such as energy efficiency, waste reduction, and improved environmentally-friendly designs (Gray \& Bebbington, 2007, p. 381). If these initiatives are combined with the traditional economic growth model, it can have serious environmental impacts (Milne, Ball \& Gray, 2005, p. 17, 19).

Increased profitability due to competitive advantages gained through eco-efficiency can encourage business to increase production, which could lead to increased absolute material and energy usage and increased waste production. Milne, Ball and Gray explained:

Improvements in dematerialisation need to come at the level of economies, and ultimately the planet, and not simply on the basis of individual products - a tenfold decrease in material inputs per computer is little use if it coincides with a greater than tenfold increase in consumption of these products. $(2005, \mathrm{p} .19)$

Environmental sustainability therefore requires a reduction in the resources used and eventually discarded in total, and not just as efficiency gains (Gray, 2006, p. 809).

A major problem with the current economic and accounting paradigm used to account for corporate behaviour and impacts is that costs of goods and services seldom reflect the full social and environmental costs of production. Corporate activity, irrespective of the level of efficiency, is a major direct and indirect cause of environmental decline through pollution, resource, and environmental service exploitation (Elliott, 2004, p. 116). In cases where these costs are externalised, the firm will be able to maximise profits through over production, which will, in turn, lead to overconsumption, leading to a point where excessive environmental and social damage is caused (Connelly \& Smith, 2003, p. 162-163). The importance of acknowledging and taking responsibility for the negative environmental impacts caused by corporate activities can be summarised as follows:

The value of dwindling natural resources and the cost of increasing atmospheric pollution should surely be included in the price we are all paying for what we buy and consume? At the moment, these costs often do not appear in anyone's books. All of these costs, for which future generations will pay dearly, are given nil values in company accounts. (Prince of Wales, 2006) 
Environmental sustainability requires companies to take an increased responsibility for negative environmental impacts caused by their operations and the full life cycle of their products. This includes the sourcing of materials and products from environmentally responsible suppliers. The following three aspects should be considered:

\section{Ecological Footprint of Operations}

The concept of accounting for carbon emissions (Terry, 2008, p. 267) is not new. Ecological foot-printing takes it further by requiring companies to account for the environmental impacts of their day-to-day activities (Visser, Matten et al, 2010, p. 148). These activities should not merely be seen as physical production, but also include the footprints created by service industries and administrative offices.

NEMA sections 4(a)(i) to 4(a)(vi) specifically require that the following should be considered:

- $\quad$ The disturbance of ecosystems and loss of biological diversity

- $\quad$ Pollution and degradation of the environment

- $\quad$ The disturbance of landscapes and sites that constitute national cultural heritage sites

- $\quad$ The use and exploitation of non-renewable natural resources

- $\quad$ The avoidance or minimisation of waste as well as responsible disposal and recycling

- $\quad$ The development, use, and exploitation of renewable resources and ecosystems within ecological limits

(South Africa, 1998)

Each of the above considerations must follow the preventative principle, which seeks to minimise environmental damage, by firstly attempting to avoid all negative impacts or "where they cannot be altogether avoided, are minimised and remedied" (Glazewski, 2005, p. 18-19).

\section{Supply Chain}

It is becoming increasingly important for companies to be able to account for the origins of the materials and products used by them, thereby ensuring transparency and traceability throughout the supply chain. Companies should consider and encourage their suppliers to consider and reduce negative environmental impacts of their activities (Daudin \& Kadjar, 2010, p. 10). Supply chain audits should be conducted and there should be well documented supplier selection criteria underlining their preference for suppliers working toward environment sustainability. Sourcing includes the sourcing of stationary as well as office and computer equipment.

\section{3. $\quad$ Product Life Cycle}

NEMA section 4(e) states that responsibility must be taken for the environmental health and safety consequences of products, processes, and services or activities throughout its life cycle (South Africa, 1998). For the purposes of this analysis, this section will be concerned with the use and eventual disposal of goods by customers as well as office equipment and vehicles that were donated by companies for re-use by schools and charities.

\section{Disclosure for Social Sustainability}

Social sustainability are the least conceptually developed of the three sustainability pillars (Cuthill, 2010, p. 363 ) and are often seen as purely philanthropic activities by the company or members of staff (Andriof \& McIntosh, 2001, p. 15; Terry, 2008, p. 141-142). It is increasingly used as a form of public relations and advertising. Sometimes referred to as "blue-washing" or "strategic philanthropy," the practise describes social responsibility which is only undertaken when it is aligned with corporate profitability (Visser, 2011b, p. 80).

Being a socially responsible business means fulfilling the entity's legal obligations, investing in human capital, stakeholder relations, fair trade, and the rights of indigenous people (Cuthill, 2010, p. 366; Terry, 2008, p. 145; Visser, 2011b, p. 119, 139). It is becoming increasingly important for firms to take responsibility for their 
sourcing practices, including human rights and labour conditions in their supply chain (Daudin \& Kadjar, 2010, p. $10)$.

Businesses cannot address sustainability without giving attention to poverty elevation (Barkemeyer et al., 2011; Terry, 2008, p. 145) by paying for their inputs and labour at fair market values. Poverty increases environmental degradation and undermines attempts at ecological sustainability (Cuthill, 2010, p. 363). In South Africa, social issues also include employment equity and Broad Based Black Economic Empowerment (BBBEE) programmes (Terry, 2008, p. 145).

The measurement of social sustainability is hampered by the fact that the impacts depend on subjective perceptions which are formed by differing social values - for example, "gender equality, which is generally regarded as a desirable contribution to social sustainability, might be judged differently in more traditional societies" (Schneider \& Meins, 2011).

Companies claiming to be socially sustainable should take responsibility for the social impacts of their operations by addressing the following three aspects:

\section{Environmental Justice}

NEMA section 4(c) states that "adverse environmental impacts shall not be distributed in such a manner as to unfairly discriminate against any person, particularly vulnerable and disadvantaged persons" (South Africa, 1998). For the financial sector, this concept will include the evaluation of the consequences of investments and the provision of financing for development projects.

\section{Labour Relations}

NEMA section 4(j) stipulates that workers have the right to refuse to perform work that is harmful to human health or the environment. It also stipulates that workers must be informed of any such dangers (South Africa, 1998).

\section{Supply Chain And Sourcing}

As mentioned earlier, companies are increasingly being held accountable for their sourcing practices. Supplier selection should include an evaluation of human rights, child labour, forced and compulsory labour, the rights of indigenous people, as well as an evaluation of the potential negative environmental and health impacts of the operations of the suppliers.

\section{Disclosure for Economic Sustainability}

The economic stability of a firm is an indispensable element of corporate sustainability (Schneider \& Meins, 2011). From a triple bottom-line perspective, financial profit, as reported in the financial statements, is often mistakenly seen as the economic benefit enjoyed by the society in which it operates. Although financial performance is critical in determining and understanding the organisation's own sustainability, it does not provide users of sustainability reports with any information regarding the organisation's contribution to the sustainability of the larger economic system in which it operates (Terry, 2008, p. 224). Financial reporting only shows "how much more rich people will receive as a result of economic activity, while ignoring how that surplus has been appropriated or calculated" (Gray, 2006, p. 798). Indeed, it can be argued that "few ideas could be more destructive to the notion of a sustainable planet than a system of economic organisation designed to maximise those things which financial reporting measures" (Gray, 2006, p. 794).

Measuring economic impacts is also hampered by the nature of operating a successful business; a successful company attempts to increase its own market share. This competition will inevitably have a negative impact on its competitors and could jeopardise the sustainability of smaller companies, which will impact their employees, communities, supply chains, etc. It is also difficult to determine when a company has grown too big for 
the economic ecosystem in which it operates. If a company were truly contributing to the economic sustainability of a local community, the community should still be able to flourish, should the company no longer be operating in that community.

Economic sustainability can only be achieved if equity - also known as social justice - is addressed. It can be described as the attempt to reverse the increasing disparities in wealth and consumption through increasing the access to environmental and other resources by disadvantaged sections of society (Gray, 2006, p. 804, 809).

Other economic issues to be addressed includes economic development, international trade, globalisation, bribery, money laundering, corruption, corporate governance, responsible corporate investments, and the economic balance of the supply chains (Terry, 2008, p. 14; Schneider \& Meins, 2011; Daudin \& Kadjar, 2010, p. 10).

Companies claiming to contribute to economic sustainability should take greater responsibility for the economic impact of their operations of local communities and the following aspect should be disclosed:

\section{Equity And Social Justice}

The question of poverty and the responsibility for social development are under pinned by NEMA Section 3(d). This principle states that everybody, especially persons who have been disadvantaged by unfair discrimination, must have equitable access to environmental resources, benefits and services to meet their basic human needs and to ensure their well-being. This principle can find expression in the ability of individuals to earn a living wage and participate in the economy and market.

\section{The Evaluation Matrix}

Based on the preceding literature and an analysis of questions used in similar studies (Deloitte, 2012; Marx \& van Dyk, 2011), the evaluation matrix depicted in Table 1 was developed. The analysis of disclosures is done according to a Likert Scale. The distinctions between the various levels of the Likert Scale is based on the quality and perceived usefulness of the information reported on by the entities (Marx \& van Dyk, 2011, p. 113). The usefulness of the disclosures was based on the degree in which the information met the qualitative characteristics, as applicable, of useful financial information as set out in the International Accounting Standards Board Conceptual Framework. These characteristics include: relevance, faithful representation (completeness, neutrality, free from errors), comparability, verifiability, timeliness, and understandability (IASB, 2010).

The Likert Scale should be interpreted as follows:

Scale 1: $\quad$ No Disclosure - This topic is not mentioned in the report.

Scale 2: Disclosure to a lesser extent - The topic is only mentioned briefly in the report (which might include measured results) with little or no context provided.

Scale 3: Disclosure to some extent - The topic and measured results are discussed and a measurable target is provided for the current and/or future.

Scale 4: Disclosure to a large extent - The current year performance is discussed against the target and mitigation is provided to improve performance.

Scale 5: Significant disclosure - Full integration is achieved by linking the risk, target, and mitigation with the financial aspects. 
Table 1: Evaluation Matrix for Sustainability Disclosures

\begin{tabular}{|c|c|c|c|c|c|c|}
\hline \multirow{2}{*}{\multicolumn{2}{|c|}{ Disclosure of the Scope of Sustainability Concerns }} & \multicolumn{5}{|c|}{ Results } \\
\hline & & 5 & 4 & 3 & 2 & 1 \\
\hline \multicolumn{7}{|c|}{ Integration } \\
\hline 1 & Are the wider context of sustainability discussed in the report? & & & & & \\
\hline 2 & $\begin{array}{l}\text { Have "SMART" targets (key performance indicators) relating to the wider sustainability agenda } \\
\text { been set and disclosed? SMART targets are Specific, Measurable, Achievable, Realistic and } \\
\text { Time-bound. }\end{array}$ & & & & & \\
\hline 3 & $\begin{array}{l}\text { Has consideration for the sustainability challenges associated with the supply chain been } \\
\text { integrated into key performance targets and objectives? }\end{array}$ & & & & & \\
\hline 4 & $\begin{array}{l}\text { Does the report demonstrate a link between the key performance indicators, identified risks, } \\
\text { corporate strategy, and targets informed by stakeholders? }\end{array}$ & & & & & \\
\hline 5 & $\begin{array}{l}\text { Is risk disclosure balanced with regards to financial, economic, social and environmental risks } \\
\text { and has a credible mitigation plan been provided? }\end{array}$ & & & & & \\
\hline 6 & $\begin{array}{l}\text { Does the organisation present a vision for the future in which sustainability challenges relevant to } \\
\text { the organisation and society are addressed? }\end{array}$ & & & & & \\
\hline \multicolumn{7}{|c|}{ Stakeholder Engagement } \\
\hline 1 & Does the report describe who the intended target audience of the Integrated Report is & & & & & \\
\hline 2 & Are the stakeholders identified and the stakeholder engagement processes disclosed? & & & & & \\
\hline 3 & $\begin{array}{l}\text { Are all stakeholder concerns made available even if they were not deemed to be material enough } \\
\text { for detailed disclosure within the report? }\end{array}$ & & & & & \\
\hline \multicolumn{7}{|c|}{ Materiality } \\
\hline 1 & Is the boundary of the report as it relates to disclosures clearly explained? & & & & & \\
\hline 2 & $\begin{array}{l}\text { Are the method used to determine materiality and the identification of material items (scope and } \\
\text { boundary) properly disclosed? }\end{array}$ & & & & & \\
\hline \multicolumn{7}{|c|}{ Transparency } \\
\hline 1 & $\begin{array}{l}\text { Is the report understandable to a wide range of stakeholders (logical structure, visually attractive } \\
\text { and concise in addition to containing an executive summary with a balanced overview of content } \\
\text { and key messages)? }\end{array}$ & & & & & \\
\hline 2 & $\begin{array}{l}\text { Are the information provided in the report compared against prior years, targets and/or industry } \\
\text { benchmarks? }\end{array}$ & & & & & \\
\hline 3 & Is the information provided sufficient to enable an independent third party to verify the claims? & & & & & \\
\hline 4 & Are the efforts undertaken to ensure accuracy of the report disclosed? & & & & & \\
\hline 5 & $\begin{array}{l}\text { Does the report contain a good balance of issues, and not only contain matters that reflect well on } \\
\text { the organisation? }\end{array}$ & & & & & \\
\hline \multicolumn{7}{|c|}{ Disclosure for Environmental Sustainability } \\
\hline \multicolumn{7}{|c|}{ Ecological Footprint of Operations } \\
\hline 1 & Are environmental impacts identified and contextualised? & & & & & \\
\hline 2 & $\begin{array}{l}\text { Are measurable targets relating to greenhouse gas emissions linked to actual reductions } \\
\text { achieved? }\end{array}$ & & & & & \\
\hline 3 & $\begin{array}{l}\text { Are there quantifiable commitments to reduce reliance on renewable and non-renewable } \\
\text { resources, including energy and water usage? This can include the use of recycled materials. }\end{array}$ & & & & & \\
\hline 4 & $\begin{array}{l}\text { Are waste and pollution associated with operations accounted for and measured, and are there } \\
\text { measurable targets set for reduction? }\end{array}$ & & & & & \\
\hline 5 & $\begin{array}{l}\text { Are significant impacts of transporting products, goods and materials including members of the } \\
\text { workforce disclosed? }\end{array}$ & & & & & \\
\hline \multicolumn{7}{|c|}{ Supply Chain } \\
\hline 1 & $\begin{array}{l}\text { Does the report contain a description of improvements in the supply chain and whether upstream } \\
\text { performance has been integrated into the organisation's sustainability strategy and improvement } \\
\text { targets? }\end{array}$ & & & & & \\
\hline 2 & $\begin{array}{l}\text { Are the company able or willing to account for the environmental impacts of their major } \\
\text { suppliers? }\end{array}$ & & & & & \\
\hline \multicolumn{7}{|c|}{ Product Life Cycle } \\
\hline 1 & $\begin{array}{l}\text { Are the life cycle stages of goods and services assessed and has downstream performance been } \\
\text { integrated into the organisation's sustainability strategy and improvement targets? This includes } \\
\text { packaging material that is reclaimed. }\end{array}$ & & & & & \\
\hline
\end{tabular}


Table 1 cont.

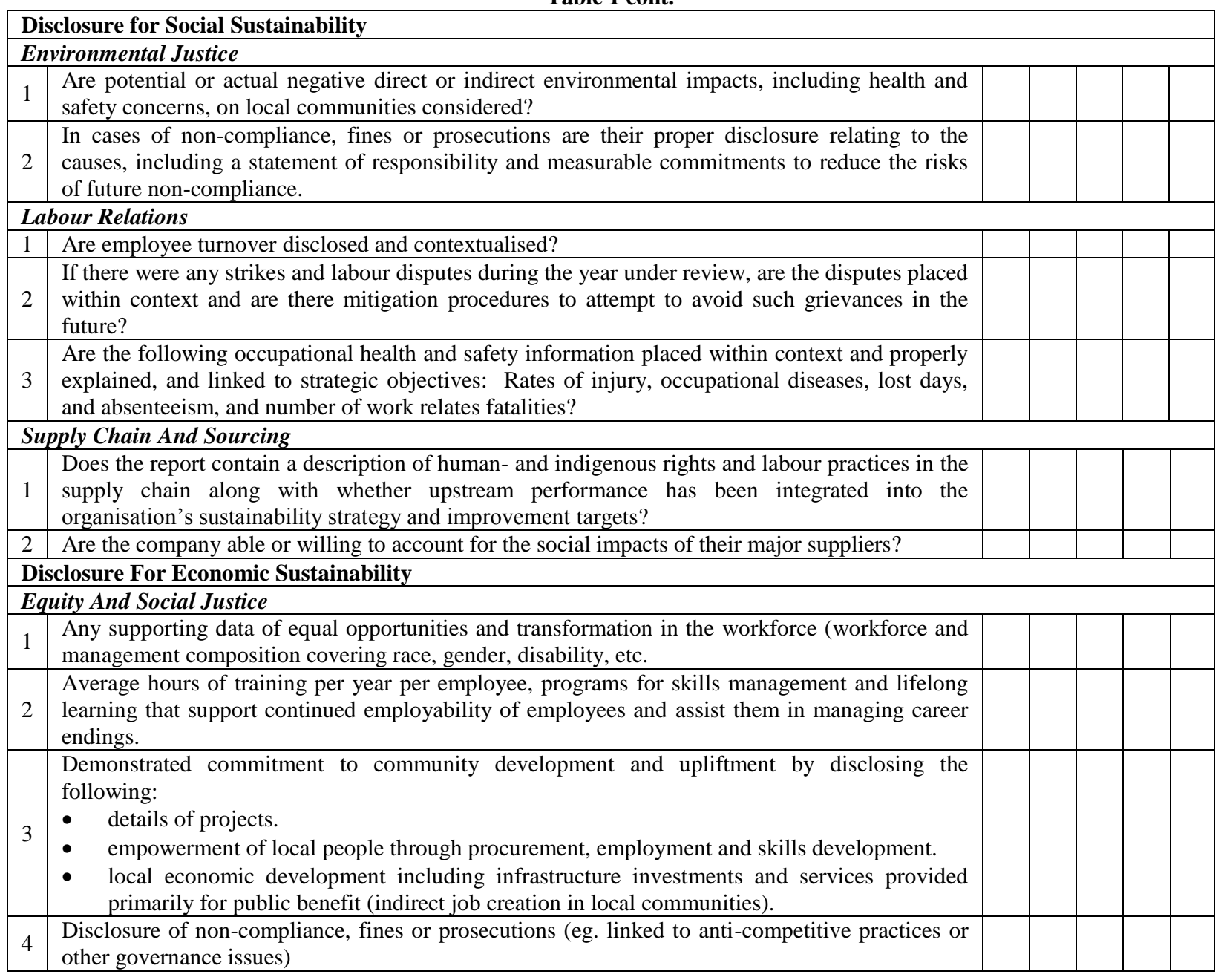

\section{EVALUATION OF SUSTAINABILITY DISCLOSURES}

\section{Methodology}

Sustainability disclosures by corporate sector entities were empirically tested through a content analysis of the Sustainability- and Integrated Reports of the companies selected for review based on the evaluation matrix as shown in Table 1. The review results for the final stand-alone sustainability reports for the year ending prior to 1 March 2010 (Generation 1 reports) were used as a baseline. The review results for the Integrated Reports created for the 2011 financial periods (Generation 2 reports) were compared against the baseline in order to determine whether there was an improvement in the disclosures.

The relevant reports were available on the relevant organisational websites and $100 \%$ coverage was obtained for the 23 companies in the sample.

This study is limited to the assessment of sustainability reporting in the relevant Sustainability Reports and Integrated Reports. Information on corporate websites, or additional reports, was only considered if the report specifically referred the reader to the website or report for additional information. These reports are considered corporate governance and stakeholder documents through which companies communicate with their stakeholders and investors (Marx \& van Dyk, 2011, p. 113; IoD, 2009, p. 12). An Integrated Report should be an organisation's primary report (IRC, 2011, p. 3; IIRC, 2011, p. 2). 
The final analysis to determine whether integrated reporting leads to an improvement in sustainability disclosures was performed by determining the movements between the Generation 1 (G1) results and the Generation 2 (G2) results and are given as follows:

- $\quad$ A marked decline represents a score for G2 which is two or more positions lower than that obtained for G1.

- A decline represents a score one position lower.

- $\quad$ No movement represents a score equal to that obtained for G1.

- An improvement represents an improvement of one position.

- $\quad$ A marked improvement represents a score of two or more positions higher.

\section{Sample}

The population selected for the empirical study comprises the best performers on the JSE SRI index for the years 2010 and 2011. From the initial list of 26 companies, a sample of 23 was selected. Only companies who formally claimed to have created an Integrated Report in 2011 were included in the final sample, the 23 companies either referred to the 2011 report as an "Integrated Report" or as an "Integrated Annual Report." The names of the 23 companies in the sample are listed in Appendix A.

The best performers are determined during an assessment performed annually by EIRIS, assisted by the Stellenbosch Business School's Unit for Corporate Governance in Africa. All companies listed in the FTSE/JSE Top 40 Index and the FTSE/JSE Mid Cap Index, or current SRI Index constituents, are automatically included in the assessment. Other listed companies can also voluntarily request to be included in the assessment (JSE, 2011b, p. 2).

\section{Findings and Deductions Relating to the Scope of Sustainability Concerns}

Table 2 shows the results obtained by companies relating to sustainability concern disclosures. The analysis of results for the level of integration achieved shows that that 14 companies (61\%) achieved no movement, one (4\%) company showed a decline, and eight (35\%) showed an improvement. In G2, all companies managed to disclose some information highlighting the level of integration, although to a lesser extent.

Risk disclosure, regarding economic, environmental and social issues, in general, has improved in G2 and the majority of companies provided a risk mitigation plan, but "the risks disclosed often lack depth and typically deal with generic risks facing corporate South Africa" (Deloitte, 2012, p. 28).

The lowest scores were obtained in the following areas:

- $\quad$ The setting of "SMART" targets

- A consideration of sustainability challenges associated with the supply chain

- A vision for the future and an understanding of future sustainability challenges for the organisation and society

Companies are still not setting measurable non-financial targets. The reason for this reluctance will have to be investigated further. It could reflect an unwillingness to make formal commitments or that the future impacts and risks are not fully understood. Deloitte (2012, p. 43) suggested that the reluctance reflects the fact that there is a "lack of consistent and reliable sustainability data."

An increasing amount of companies are mentioning the importance of considering sustainability in supply chain management. This has, however, not been fully incorporated into corporate strategies and targets. Supply chain management will be discussed further in later sections.

The disclosure of stakeholder engagement has improved. The analysis showed that eight (35\%) companies showed an improvement, with one (4\%) showing a marked improvement. However, three companies (13\%) showed a decline and 11 (48\%) showed no movement. 
Areas identified that still require considerable improvement include:

- $\quad$ The identification of the target audience for the Integrated Report

- The rationale for choosing the stakeholders and measures taken to ensure that certain stakeholder groups were not marginalised and excluded

- $\quad$ The linkage between concerns raised by stakeholders and the material issues that are actually identified and discussed

Table 2: Disclosures Relating to Sustainability Concerns

\begin{tabular}{|c|c|c|c|c|c|c|}
\hline & $\begin{array}{c}\text { No } \\
\text { Disclosure }\end{array}$ & $\begin{array}{c}\text { To A Lessor } \\
\text { Extent }\end{array}$ & $\begin{array}{c}\text { To Some } \\
\text { Extent }\end{array}$ & $\begin{array}{c}\text { To A Large } \\
\text { Extent }\end{array}$ & $\begin{array}{l}\text { Significant } \\
\text { Disclosure }\end{array}$ & Total \\
\hline First Generation (G1) & $26(28 \%)$ & $60(65 \%)$ & $6(7 \%)$ & - & - & 92 \\
\hline Integration & $6(26 \%)$ & $16(70 \%)$ & $1(4 \%)$ & - & - & 23 \\
\hline Stakeholder Engagement & $5(22 \%)$ & $15(65 \%)$ & $3(13 \%)$ & - & - & 23 \\
\hline Materiality & $10(43 \%)$ & $12(52 \%)$ & $1(4 \%)$ & - & - & 23 \\
\hline Transparency & $5(22 \%)$ & $17(74 \%)$ & $1(4 \%)$ & - & - & 23 \\
\hline Second Generation (G2) & $7(8 \%)$ & $71(77 \%)$ & $13(14 \%)$ & $1(1 \%)$ & & 92 \\
\hline Integration & - & $21(91 \%)$ & $2(9 \%)$ & - & - & 23 \\
\hline Stakeholder Engagement & $2(9 \%)$ & $15(65 \%)$ & $5(22 \%)$ & $1(4 \%)$ & - & 23 \\
\hline Materiality & $3(13 \%)$ & $17(74 \%)$ & $3(13 \%)$ & - & - & 23 \\
\hline \multirow[t]{2}{*}{ Transparency } & $2(9 \%)$ & $18(78 \%)$ & $3(13 \%)$ & - & - & 23 \\
\hline & 33 & 131 & 19 & 1 & - & 184 \\
\hline
\end{tabular}

Although there was an improvement in the overall scores achieved regarding materiality disclosure, with only $13 \%$ of companies not attempting to disclose any information regarding the determination of materiality, the overall quality of the information remains low. Overall, 13 (57\%) of the companies showed an improvement, with one (4\%) showing a marked decline and two (9\%) a decline. Seven (30\%) companies showed no movement.

Transparency in this study mainly focussed on third-party verification or assurance. The study found that $16(70 \%)$ companies showed no movement, with one (4\%) showing a decline and six (26\%) companies showing an improvement. However, transparency-related issues are only mentioned by $78 \%$ of the companies examined. $13 \%$ companies started to provide more specific information, specifically relating to the various levels of assurance obtained for the information contained within the reports. The low scores reflected the fact that the level of independent assurance on the non-financial information is still low and haphazard.

\section{Findings and Deductions Relating to Environmental Sustainability}

As can be seen from Table 3, the disclosures relating to environmental sustainability are still very low. Most companies are involved in the carbon disclosure project and many have also now started to measure water consumption. Although $\mathrm{CO}_{2}$ emissions and water used are measured and disclosed, few companies contextualise why these disclosures are made. Companies who made an attempt to contextualise their disclosures noted that $\mathrm{CO} 2$ emissions are directly related to the fact that most of the electricity in South Africa is generated using coal-fired power plants. Companies who disclose energy usage identified the cost of electricity and the security of electricity supply as key risks.

Air pollution is measured by some companies and compliance to the new Air Quality regulations are given as the main risk factor. Some companies are beginning to measure waste to landfill, with only one company disclosing income generated by re-use and disposal of their waste products.

As mentioned in the previous section, the setting of targets is still very low - only two (9\%) companies showed an improvement. Worryingly, five (22\%) of the companies showed a decline in their disclosure, with the percentage of companies making no disclosures also increasing to $22 \%$ (from 13\%). More work will need to be conducted to fully explain this trend, but it can indicate the fact that some companies do not fully understand the importance of environmental impacts and that it therefore has not been incorporated into their core business 
strategies. This analysis concurred with research conducted by Deloitte who found that the sustainable development agenda remained one of the lowest scoring elements of their Integrated Reporting analysis (Deloitte, 2012, p. 47).

Deloitte also mentioned that the sustainability agenda has not yet been translated into future strategies and targets by many companies. They concluded that it could be an indication of a "lack of maturity of most companies' sustainability process within the context of their existing business strategy" (Deloitte, 2012, p. 47).

Table 3: Disclosures Relating to Environmental Sustainability

\begin{tabular}{|c|c|c|c|c|c|c|}
\hline & $\begin{array}{c}\text { No } \\
\text { Disclosure } \\
\end{array}$ & $\begin{array}{c}\text { To A Lessor } \\
\text { Extent }\end{array}$ & $\begin{array}{c}\text { To Some } \\
\text { Extent }\end{array}$ & $\begin{array}{c}\text { To A Large } \\
\text { Extent }\end{array}$ & $\begin{array}{l}\text { Significant } \\
\text { Disclosure }\end{array}$ & Total \\
\hline First Generation (G1) & $28(40 \%)$ & $37(54 \%)$ & $4(6 \%)$ & - & - & 69 \\
\hline $\begin{array}{l}\text { Ecological Footprint of } \\
\text { Operations }\end{array}$ & $3(13 \%)$ & $19(83 \%)$ & $1(4 \%)$ & - & - & 23 \\
\hline Supply Chain & $14(61 \%)$ & $9(39 \%)$ & - & - & - & 23 \\
\hline Product Life Cycle & $11(48 \%)$ & $9(39 \%)$ & $3(13 \%)$ & - & - & 23 \\
\hline Second Generation (G2) & $32(47 \%)$ & $34(49 \%)$ & $3(4 \%)$ & - & - & 69 \\
\hline $\begin{array}{l}\text { Ecological Footprint of } \\
\text { Operations }\end{array}$ & $5(22 \%)$ & $18(78 \%)$ & - & - & - & 23 \\
\hline Supply Chain & $16(70 \%)$ & $7(30 \%)$ & - & - & - & 23 \\
\hline \multirow[t]{2}{*}{ Product Life Cycle } & $11(48 \%)$ & $9(39 \%)$ & $3(13 \%)$ & - & - & 23 \\
\hline & 60 & 71 & 7 & - & - & 138 \\
\hline
\end{tabular}

As mentioned in the previous section, supply chain management has received little attention in business strategies, with $70 \%$ of companies (G1: 61\%) making no disclosure relating to the environmental impact of their supply chain.

The level of disclosure relating to the environmental impact of the product life cycle remained constant for G1 and G2 with $48 \%$ of companies making no disclosures, 39\% disclosing impacts to a lesser extent, and $13 \%$ of companies making disclosures to some extent. This, however, conceals the fact that four $(17.5 \%)$ companies showed a decline and four (17.5\%) showed an improvement.

\section{Findings and Deductions Relating to the Scope of Social Sustainability}

In general, social sustainability issues and, more specifically, environmental justice issues received little attention as can be seen in Table 4. This can be a reflection of the fact that many companies find it difficult to contextualise their impacts. Three (13\%) companies showed an improvement, while seven (30\%) of the companies showed a decline in their disclosure. This increases the total number of companies who made no disclosures to $57 \%$ (G1 39\%). The remainder of the companies (43\%) made disclosures to a lesser extent (G1 61\%).

Table 4: Disclosures Relating to Social Sustainability

\begin{tabular}{|c|c|c|c|c|c|c|}
\hline & $\begin{array}{c}\text { No } \\
\text { Disclosure }\end{array}$ & $\begin{array}{l}\text { To A Lessor } \\
\text { Extent }\end{array}$ & $\begin{array}{c}\text { To Some } \\
\text { Extent }\end{array}$ & $\begin{array}{c}\text { To A Large } \\
\text { Extent }\end{array}$ & $\begin{array}{l}\text { Significant } \\
\text { Disclosure }\end{array}$ & Total \\
\hline First Generation (G1) & $39(56 \%)$ & $28(41 \%)$ & $2(3 \%)$ & & & 69 \\
\hline Environmental Justice & $9(39 \%)$ & $14(61 \%)$ & - & - & - & 23 \\
\hline Labour relations & $10(43 \%)$ & $11(48 \%)$ & $2(9 \%)$ & - & - & 23 \\
\hline $\begin{array}{l}\text { Supply chain and } \\
\text { sourcing }\end{array}$ & $20(87 \%)$ & $3(13 \%)$ & - & - & - & 23 \\
\hline Second Generation (G2) & $42(61 \%)$ & $27(39 \%)$ & & & & 69 \\
\hline Environmental Justice & $13(57 \%)$ & $10(43 \%)$ & - & - & - & 23 \\
\hline Labour relations & $8(35 \%)$ & $15(65 \%)$ & - & - & - & 23 \\
\hline \multirow[t]{2}{*}{$\begin{array}{l}\text { Supply chain and } \\
\text { sourcing }\end{array}$} & $21(91 \%)$ & $2(9 \%)$ & - & - & - & 23 \\
\hline & 81 & 55 & 2 & - & - & 138 \\
\hline
\end{tabular}


Staff turnover figures are disclosed but seldom contextualised. Similarly, lost time due to fatal injuries and fatality figures are disclosed, but few companies disclose the causes and remedial steps taken in cases where performance declined. The number of companies disclosing labour relation issues increased from $48 \%$ in $\mathrm{G} 1$ to $65 \%$ in $\mathrm{G} 2$.

As seen in the previous section, supply chain and sourcing remains an area requiring considerable attention. The amount of companies making no disclosure increased from $87 \%$ in G1 to $91 \%$ in G2. The remaining companies made disclosures to a lesser extent.

\section{Findings and Deductions Relating to the Scope of Economic Sustainability}

In the South African context, equity and social justice disclosures centre around BBBEE and disclosure tends to focus on Employment Equity scorecards, employee training, preferential procurement from BBBEE certified companies and philanthropic activities. Little attempt is made to contextualise the impacts of these activities, as can be seen in Table 5, nor is any consideration given to the impact of preferential procurement practices on the local communities. The majority of companies - 83\% (19) - did not make any changes to their disclosure practices, one company (4\%) showed an improvement, three (13\%) showed a decline, and the percentage of non-disclosure increased to $22 \%$. Ernst \& Young observed that there has been a reduction in the amount of general discussions and case studies, "particularly in relation to corporate social investment" $(2011$, p. 17). This might partially explain the increased non-disclosure, but further research will be required.

Table 5: Disclosures Relating to Economic Sustainability

\begin{tabular}{|c|c|c|c|c|c|c|}
\hline & $\begin{array}{c}\text { No } \\
\text { Disclosure }\end{array}$ & $\begin{array}{c}\text { To A Lessor } \\
\text { Extent }\end{array}$ & $\begin{array}{c}\text { To Some } \\
\text { Extent }\end{array}$ & $\begin{array}{c}\text { To A Large } \\
\text { Extent }\end{array}$ & $\begin{array}{c}\text { Significant } \\
\text { Disclosure }\end{array}$ & Total \\
\hline First Generation (G1) & & & & & & \\
\hline Equity and social justice & $3(13 \%)$ & $19(83 \%)$ & $1(4 \%)$ & - & & - \\
\hline & & & & & & \\
\hline Second Generation (G2) & & & & & & \\
\hline Equity and social justice & $5(22 \%)$ & $17(74 \%)$ & $1(4 \%)$ & - & - & 23 \\
\hline & $\mathbf{8}$ & $\mathbf{3 6}$ & $\mathbf{2}$ & - & - & $\mathbf{4 6}$ \\
\hline
\end{tabular}

\section{CONCLUSION AND AREAS FOR FUTURE RESEARCH}

Humanity is currently facing multiple crises ranging from a global financial recession, increased socioeconomic inequality, dwindling natural resources, fears surrounding food and water security, climate change, ecosystem degradation, and the loss of biodiversity. This "poly-crisis" has highlighted the fact that the current development paradigm and the underlying business models are environmentally and socially unsustainable.

The transition towards a new "green" development paradigm that is built on a more equitable, low-carbon, resource-productive and zero-waste economy will require a fundamental change in the way companies operate and conduct themselves. This, in turn, will require companies to regain stakeholder trust by addressing the weaknesses in current reporting practices in order to become more accountable and transparent.

King III recommends the adoption of Integrated Reporting and the Integrated Report as an important element to help companies undergo the important changes needed to address the multiple crises faced by humanity and companies. The production of an Integrated Report is a JSE listing requirement, on a report or explain basis, since March 2010.

Broadly speaking, the Integrated Report and Integrated Reporting process can lead to a change in corporate behaviour in two ways. The first reflects the ideal cycle, as envisioned by King III, in which the integrated reporting process starts with a realisation by the board and management regarding the sustainability risks and negative impacts experienced by society and the environment as a result of the company's operations. This leads to the integration of sustainability into the core business strategy, and the Integrated Report serves as a tool used by the board to communicate with stakeholders regarding the progress and challenges experienced in becoming more sustainable. 
The alternative method, adopted by the majority of companies, starts with the creation of an Integrated Report. This method could still ensure the necessary change in corporate behaviour if the Integrated Report contains sufficient information to highlight the weaknesses in the current corporate strategy and identify areas requiring improvement and attention by management and the board. In this way, the report can trigger the necessary changes in corporate behaviour and could theoretically move companies toward becoming more sustainable.

The study found that although many companies are attempting or claiming to be creating Integrated Reports, the level of integration and the understanding of what a truly Integrated Report should represent is still very low. The research results suggest that companies are still caught in the "out-dated approach of value creation" (Porter \& Kramer, 2011, p. 64) and that few companies have incorporated and understood the importance of environmental and societal influences in achieving long-term success (Hanks \& Gardiner, 2012, p. 14).

The Integrated Reporting process is still in the development phase with many companies only now developing methodologies to measure their various impacts. There are a few companies who are clearly committed to Integrated Reporting and their reports are starting to reflect information that can potentially lead to changes in business strategies.

This analysis found that the measurement methodologies employed by the majority of companies are haphazard. Few companies clearly explain how these impacts are reflected in the corporate strategy or attempt to provide a context to explain how they impact not only the business, but society, the environment, and/or the economy. The information contained within these reports is unlikely to lead to fundamental changes within the reporting process and will therefore not lead to the adoption of more sustainable business strategies.

Companies, whose main motivation for producing an Integrated Report is compliance, are more likely to adopt a "tick-box" approach to disclosure, disclosing the minimum information required, without contextualising the information. They are also more likely to only disclose positive impacts.

Future research should focus on developing clear disclosure guidelines regarding all aspects of integrated reporting, especially regarding disclosures relating to materiality, stakeholder engagement, and the sustainable development agenda and impacts. This will assist companies who are currently spending considerable resources and time on improving these processes to get the recognition they deserve by improving the manner in which they are reporting on these activities. It will also force companies who are currently claiming to be producing an Integrated Report but who have not yet voluntarily embarked on the integrated reporting process to adopt prescribed business activities and strategies to enable them to produce the specific and robust data required for the preparation of an Integrated Report.

\section{AUTHOR INFORMATION}

Anria S. van Zyl is a qualified Chartered Accountant, currently lecturing Information Systems at undergraduate level at the University of Stellenbosch. She holds a Master's degree in Computer Auditing as well as an MPhil in Environmental Management from the University of Stellenbosch. E-mail: avanzyl@ sun.ac.za

\section{REFERENCES}

1. Accounting for Sustainability (A4S) (2007). Connected reporting: A practical guide with worked examples. The Prince's Accounting for Sustainability project: London.

2. Andriof, J., \& McIntosh, M. (2001). Perspectives on corporate citizenship. United Kingdom: Greenleaf Publishing.

3. Barkemeyer, R., Holt, D., Preuss, L., \& Tsang, S. (2011). What happened to the "Development" in Sustainable Development? Business Guidelines Two Decades After Brundtland. Sustainable Development. [DOI: 10/1102/sc.521].

4. Borrini-Feyerabend, G., Pimbert, M., Farvar, M. T., Kothari, A., \& Renard, Y. (2004). Co-management of natural resources. In Sharing Power - Learning by doing in co-management of natural resources throughout the world (pp. 64-107). Cenesta, Tehran: IIEED \& IUCN/CEESP/CMWG. 
5. Clarke, R. E., Willis, C. B., \& Brown, P. J. (2000). A generic approach to policy formulation in South Africa. CSIR Internal Report. Pretoria: CSIR.

6. Christian Aid (2004). Behind the mask: The real face of corporate social responsibility. London: Christina Aid.

7. Connelly, J., \& Smith, G. (2003). Choosing the means. In Politics and the environment (pp. 157-186). London: Routledge.

8. Cooper, S. M., \& Owen, D. L. (2007). Corporate social reporting and stakeholder accountability: The missing link. Accounting, Organizations and Society, 23(2007), 649-667.

9. Cuthill, M. (2010). Strengthening the "social" in sustainable development: Developing a conceptual framework for social sustainability in a rapid urban growth region in Australia. Sustainable Development, 18(2010), 362-373.

10. Daudin, M., \& Kadjar, H. (2010). Sustainable procurement reporting by major international groups: Analysis of the external communication of 125 Asian, American and European companies from the Global 500. Paris, France: ORSE \& Ecovadis.

11. Deloitte (2012). Integrated reporting: Navigating your way to a truly integrated report. Edition 2 - February 2012. Johannesburg: Deloitte \& Touche.

12. Department of Environmental Affairs and Tourism (DEAT) (2010). National climate change response greenpaper. Retrieved from www.environmental.gov.za

13. Diamond, J. (2011). Collapse: How societies choose to fail or succeed. (New Edition). New York: Penguin Books.

14. Eccles, R. G., \& Krzus, M. P. (2010). One report: Integrated reporting for a sustainable strategy. New Jersey: John Wiley \& Sons, Inc.

15. Eccles, R. G., \& Armbrester, K. (2011). Two disruptive ideas combined: Integrated reporting in the cloud. IESEInsight, 8(first quarter), 13-20.

16. Economist, The (2009). Triple bottom-line. It consists of three Ps: profit, people and planet. Retrieved from http://www.economist.com/node/14301663

17. Elliott, L. (2004). Global environmental governance: Democratization and local voices. In The global politics of the environment (pp. 113-136). New York: New York University Press.

18. Ernst \& Young (2011). Excellence in corporate reporting 2011: A survey of annual reports from South Africa's top 100 companies and top 10 state-owned entities. South Africa: Ernst \& Young.

19. Fisher-Kowalski, M. (2011). Analysing sustainability transitions as a shift between socio-metabolic regimes. Environmental Innovation and Societal Transitions, 1(2011), 152-159.

20. Glazewski, J. (2005). Environmental law in South Africa (2nd ed.). Durban, South Africa: LexisNexis.

21. Global Reporting Initiative (GRI) (2011). Sustainability reporting guidelines (Version 3.1). Amsterdam: GRI.

22. Gore, C. (2010). The global recession of 2009 in a long-term development cycle perspective. Journal of International Development, 22(2010), 714-738.

23. Gray, R., \& Bebbington, J. (2007). Corporate sustainability: Accountability or impossible dream? In G. Atkinson, S. Dietz, \& E. Neumayer (eds). Handbook of sustainable development (pp. 376-391). Cheltenham, UK: Edward Elgar Publishing.

24. Gray, R. (2006). Social, environmental and sustainability reporting and organisational value creation? Whose value? Whose creation? Accounting, Auditing \&Accountability Journal, 19(6), 793-819.

25. Gray, R. (2010). Is accounting for sustainability actually accounting for sustainability... and how would we know? An exploration of narratives of organisations and the planet. Accounting, Organizations and Society, 35(2010), 47-62.

26. Gray, R. (2012). Integrated reporting: Integrated with what and for whom? The Loop: Issue 5. Safety, Environment \& Quality Management (SEQM). Retrieved from http://theloop.seqm.com/2012/02/13/integrated-reporting/

27. Haberl, H., Fisher-Kowalski, M., Krausmann, F., Martinez-Alier, J., \& Winiwarter, V. (2011). A sociometabolic transition towards sustainability? challenges for another transformation. Sustainabile Development, 19(2011), 1-14.

28. Hanks, J., \& Gardiner, L. (2012). Private sector opinion - Integrated reporting: Lessons from the South African experience. A Global Corporate Governance Forum Publication. Issue 25. International Finance Corporation: Washington, DC. 
29. Institute of Directors (IoD) (2009). 2011/2012 SAIGR Wetgewinghandboek: The King III Report and Code on Governance In South Africa. Volume 3. Durban: LexisNexis.

30. Institute of Directors (IoD) (2011). Code for responsible investing In South Africa (CRISA). Committee on Responsible Investing by Institutional Investors in South Africa. Retrieved from http://www.iodsa.co.za/PRODUCTSSERVICES/KingIIIReportPapersGuidelines/CodeforResponsibleInves tinginSACRISA.aspx

31. Institute of Directors (IoD) (2012). Practice notes: King III Chapter 9 - The Integrated Report. Retrieved from: http://www.iodsa.co.za/PRODUCTSSERVICES/KingIIIReportPapersGuidelines/KingReport onCorporateGovernanceinSA/KingIIIPracticeNotes.aspx

32. Integrated Reporting Committee (IRC) (2011). Framework for integrated reporting and the integrated report: Discussion paper. Integrated Reporting Committee of South Africa. Retrieved from https://www.saica.co.za/TechnicalInformation/SustainabilityandIntegrated

Reporting/TheIRCsDiscussionPaper/tabid/2372/language/en-za/Default.aspx

33. International Accounting Standards Board (IASB) (2010). Conceptual Framework for Financial Reporting. Retrieved from https://www.iasb.org

34. International Integrated Reporting Committee (IIRC) (2011). Towards integrated reporting: Communicating value in the $21^{\text {st }}$ century. International Integrated Reporting Committee. Retrieved from www.theiirc.org

35. Johannesburg Stock Exchange (JSE) (2010). Best performers 2010. JSE and EIRIS. Retrieved from http://www.jse.co.za/About-Us/SRI/Results/SRI2010Results.aspx

36. Johannesburg Stock Exchange (JSE) (2011a). Best performers 2011. JSE and EIRIS. Retrieved from http://www.jse.co.za/About-Us/SRI/Results/SRI2011Results.aspx

37. Johannesburg Stock Exchange (JSE) (2011b). SRI index: Background and selection criteria 2011. JSE and EIRIS. Retrieved from www.jse.co.za/About-Us/SRI/Criteria.aspx

38. King, M.E. (2011). Foreword. In integrated reporting committee (irc) framework for integrated reporting and the integrated report: Discussion paper. Integrated Reporting Committee of South Africa. Retrieved from http://www.sustainailitysa.org

39. Kotzé, L. J. (2009). Environmental governance. In A. Paterson, \& L. J. Kotzé (eds) Environmental compliance and enforcement in South Africa: Legal perspectives (pp. 103-125). Claremont South Africa: Juta Law.

40. Maathai, W. (2009). The challenge for Africa: A new vision. London: Random House.

41. Marx, B., \& van Dyk, V. (2011). Sustainability reporting at large public sector entities in South Africa. $S A$ Journal of Accounting Research, 25(1), 103-127.

42. Massie, R. K. (2010). Accounting and accountability: Integrated reporting and the purpose of the firm. In R. G. Eccles, B. Cheng, \& D. Saltzman (eds) 2010. The landscape of integrated reporting: Reflections and next steps. Cambridge: Harvard Business School.

43. Milne, M. J., Ball, A., \& Gray, R. (2005). From soothing palliatives and towards ecological literacy: A critique on the Triple Bottom-line. Unpublished. Presented at the $16^{\text {th }}$ International Conference on Social and Environmental Accounting Research, 30 March - 1 April 2005. Retrieved from http://otago.ourarchive.ac.nz/handle/10523/1551

44. Munshi, D., \& Kurian, P. (2005). Imperializing spin cycles: A postcolonial look at public relations, greenwashing, and the separation of publics. Public Relations Review, 31, 513-520.

45 National Treasury (2010). Discussion paper for public comment-Reducing greenhouse gas emissions: The carbon tax option. Retrieved from www.treasury.gov.za

46. Norman, W., \& MacDonald, C. (2004). Getting to the bottom of "triple bottom-line". Business Ethics Quarterly, 14(2), 243-262.

47. Perez, C. (2009). The double bubble at the turn of the century: technological roots and structural implications. Cambridge Journal of Economics, 33, 779-805.

48. Perez, C. (2010). The advance of technology and major bubble collapses: Historical regularities and lessons for today. Paper presented at the Engelsberg Seminar on the Future of Capitalism. Une. Ax: son Foundation: Sweden.

49. Porter, M. E., \& Kramer, M. R. (2006). Strategy \& society: The link between competitive advantage and corporate social responsibility. Harvard Business Review. May, 78-92. 
50. Porter, M. E., \& Kramer, M. R. (2011). The big idea: Creating shared value: How to reinvent capitalismand unleash a wave of innovation and growth. Harvard Business Review. January-February, 63-77.

51. Prince of Whales (2006). Speech by his royal highness, prince of Wales on the launch of the accounting for sustainability project. 6 December 2006. Retrieved from http://www.accountingforsustainability.org.uk/files/pdf/A4S\%20HRH\%20Speech.pdf

52. Robb, G., Tyler, E., \& Cloete, B. (2010). Carbon trading or carbon tax? Weighing up South Africa's mitigation options. In H. Winkler, A. Marquard, \& M. Jooste (eds). Putting a price on carbon: Economic instruments to mitigate climate change in South Africa and other developing countries (pp. 196-213).

Proceedings of the conference held at the University of Cape Town 23-24 March 2010. Energy and Research Centre, University of Cape Town: Cape Town.

53. Roberts, S., Keeble, J., \& Brown, D. (2002). The business case for corporate citizenship. Arthur D. Little: Business in the Community. Retrieved from http://www.adlittle.co.uk/publications_uk.html?extsearch=business+case+for+corporate

54. Schneider, A., \& Meins, E. (2011). Two dimensions of corporate sustainability assessment: Towards a comprehensive framework. Business Strategy and the Environment 2011. Retrieved from wileyonlinelibrary.com

55. Spence, C., \& Gray, R. (2007). Social and environmental reporting and the business case. London: Certified Accountants Educational Trust.

56. South Africa (1996). Constitution of the Republic of South Africa no 108, 1996. Government Printer: Pretoria.

57. South Africa (1998). National Environmental Management Act no 107, 1998. Government Printer: Pretoria.

58. South Africa (2000). The Promotion of Access to Information Act 2, 2000. Government Printer: Pretoria.

59. Swilling, M., \& Annecke, E. (2012). Just transitions: Explorations of sustainability in an unfair world. Cape Town: UCT Press.

60. Tapscott, D. (2010). Foreword. In R. G. Eccles, \& M. P. Krzus. One report: Integrated reporting for a sustainable strategy (pp. ix-xiv). New Jersey: John Wiley \& Sons, Inc.

61. Terry, G. (2008). Green: Why corporate leaders need to embrace sustainability to ensure future profitability. Kengray, South Africa: The South African Institute of Chartered Accountants.

62. U.N. (2012a). Resilient people, resilient planet: a future worth choosing. $66^{\text {th }}$ session. Agenda item 19(a): Sustainable development: Implementation of Agenda 21, the Programme for the Further Implementation of Agenda 21 and the outcomes of the World Summit on Sustainable Development. U.N. General Assembly: New York. Retrieved from http://www.un.org/ga/search/view_doc.asp?symbol= A/66/700

63. U.N. (2012b). The future we want. Agenda item 10: Outcome of the RIO+20 conference. U.N. Conference on sustainable Development. Rio de Janeiro, Brazil. 20-22 June 2012. Retrieved from http://rio20.net/en/iniciativas/the-future-we-want-final-document-of-the-rio20-conference

64. Visser, W., Matten, D., Pohl, M., \& Tolhurst, N. (2010). The A-Z of corporate social responsibility. Chichester, United Kingdom: John Wiley \& Sons, Inc.

65. Visser, W. (2011a). The age of responsibility: CSR 2.0 and the new DNA of business. Journal of Business Systems, Governance and Ethics, 5(3), 7-22.

66. Visser, W. (2011b). The age of responsibility: CSR 2.0 and the new DNA of business. Chichester, United Kingdom: John Wiley \& Sons.

67. Zukang, S. (2011). Overview. In UN World Economic and Social Survey 2011: The Great Green Technological Transformation. New York: United Nations Department of Economic and Social Affairs. 
APPENDIX A

JSE SRI Index Best Performers for the Years 2010 and 2011

\begin{tabular}{|l|l|c|}
\hline & \multicolumn{1}{|c|}{ Company Name } & Environmental Impact \\
\hline 1 & AngloGold Ashanti High \\
\hline 2 & ArcelorMittal South Africa & High \\
\hline 3 & Exxaro Resources & High \\
\hline 4 & Gold Fields Limited & High \\
\hline 5 & Group Five & High \\
\hline 6 & Impala Platinum Holdings & High \\
\hline 7 & Kumba Iron Ore & High \\
\hline 8 & Merafe Resources & High \\
\hline 9 & Mondi & High \\
\hline 10 & Murray \& Robberts & High \\
\hline 11 & Pretoria Portland Cement & High \\
\hline 12 & Sappi & High \\
\hline 13 & Tongaat Hulett & High \\
\hline 14 & Woolworths Holdings & Medium \\
\hline 15 & Barloworld Limited & Medium \\
\hline 16 & Massmart Holdings Limited & Medium \\
\hline 17 & Steinhoff International Holdings & Low \\
\hline 18 & ABSA Group & Low \\
\hline 19 & The Bidvest Group & Low \\
\hline 20 & Sanlam & Low \\
\hline 21 & Santam Limited & Low \\
\hline 22 & Standard Bank Group & Low \\
\hline 23 & Vodacom Group Limited & \\
\hline
\end{tabular}

(JSE 2010, 2011a) 